\title{
Production Aspect as the Most Important Factor in the Development of Halal Small and Medium Industries (SMIs)
}

\author{
$1^{\text {st }}$ Syaeful Bakhri \\ Faculty of Sharia and Islamic \\ Economics of IAIN Syekh Nurjati of \\ Cirebon \\ Indonesia \\ sultan01aulia@yahoo.com \\ $4^{\text {th }}$ Cucu Herawati \\ Public Health Department \\ Health Science Institute of Cirebon \\ Indonesia
}

\author{
$2^{\text {nd }}$ Layaman \\ Faculty of Sharia and Islamic \\ Economics of IAIN Syekh Nurjati of \\ Cirebon \\ $5^{\text {th }}$ Moh Yudi Mahadianto \\ Faculty of Economicsof Swadaya \\ Gunung Jati University of Cirebon \\ Indonesia
}

$3^{\text {rd }}$ Toto Suharto

Faculty of Sharia and Islamic

Economics of IAIN Syekh Nurjati of

Cirebon

\begin{abstract}
The development of the number of SMIs has not been able to encourage the increase of halal SMIs, as indicated that of 14,282 business units in 2018, only $426(3 \%)$ of the SMIs products in Cirebon District had halal certificates. This study aims to determine the policy priorities that can be taken by the Government in the context of developing halal SMIs. This was a qualitative study. The data collection method used here was Focus Group Discussion (FGD) with a total of 10 respondents from the SMIs business actors and Regional Apparatus Organization (RAO) related to the development of SMIs. Data analysis used hierarchical analysis, with the aim of solving complex problems by structuring a hierarchy of criteria in order to develop weights or priorities. The results showed that in a hierarchical sequence, production aspect(availability of raw materials and tools and machinery) was the first priority (25.79), then it was followed by HR aspect (24.94), market and marketing aspect (22.84) in an effort to improve the competitiveness of Halal SMIs. There is a need to increase good and sustainable synergy between SMIs and Local Governments in the context of achieving Halal District.
\end{abstract}

\section{Keywords-Halal Small, Medium, Industries}

\section{INTRODUCTION}

In facing the development of free trade, through national government policy, Indonesia needs to develop competitive policies as a strategic foothold in various aspects of competence in all economic sectors including the Small and Medium Industries (SMIs)sector. The Small and Medium Industries (SMIs)Sector is one of the most important sectors as the backbone of the Indonesian economy, because this sector is not only able to be a driver of the economy, but also able to be a source of livelihood for community development[1].In line with this opinion, the Government through the Ministry of Industry is currently focusing on expanding the distribution of Small and Medium Industries in various regions such as in Java and outside Java.

Based on observation, Small and Medium Industries (SMIs) in Cirebon District itself continue to experience growth. In 2017 it reached 14,282 business units, in 2018 there was an increase of $1.68 \%$ from the previous year to 14,526 units. In line with the development of the number of Small and Medium Industries, it seems that the number of halal Small and Medium Industries in Cirebon District also continues to increase. The number of Halal Small and Medium Industries in 2017 which amounted to 321 units, increased to 429 units by the end of 2018 . However, the data on the development of the number of halal SMIs is still very far in comparison with the number of SMIs as a whole. In 2018, of total 14,282 SMI business units, there were only $3 \%$ of SMIs in Cirebon regencies which were certifiedas Halal[2].

Halal food products are a major requirement for the fulfillment of food consumed by Muslim consumers throughout the world[3].The Muslim population in Cirebon District reached 2,179,787 (99\%) of 2,189,785 people[4].This shows a big opportunities as well as challenges of the Government in the development of Halal Small and Medium Industries in Cirebon District as a Halal District.

The development of SMIs is deemed necessary since Cirebon District has supporting natural resources. In the framework of developing SMIs in Cirebon District, the Ministry of Industry and Trade needs to make various efforts such as adding personnel in such field, conducting counselling, training, guiding controlling efforts and granting Intellectual PropertyRights(IPR) facilities such 
as granting patents and labelling, and conducting packaging training so that the products can be seemed more attractive[5].The development of halal SMIs needs support from various aspects, including: HR, finance, market and marketing, production, and Government policy. Based on previous studies, it was indicated that production aspect could influence the development of competitive Small and Medium Industries. Furthermore, production activities would not be realized without the availability of tools or objects needed to produce an item[6], [7].

The limited data on the development of halal small and medium industries can hamper Government policies in developing halal Small and Medium Industries. Until now there has been no analytical study on the aspects with the most significanteffect on the development of Halal Small and Medium Industries in Cirebon District, especially in several aspects that are able to encourage the competitiveness of SMEs. Thus the purpose of this research is to find out what aspects of the policy priorities can be taken by the Government in the context of developing halal SMIs.

\section{METHODS}

This was a qualitative study. The data collection method used here was Focus Group Discussion (FGD) which is an approach that descriptively reveals the findings obtained based on naturalistic findings on study objects in the form of humans, cases, phenomena and social situations [8]. This Focus Group Discussion (FGD) aims to obtain information and data from various Small and Medium Industries which have been certified as Halal and Government Agencies related to the efforts to develop Halal Small and Medium Industries in Cirebon District. The number of respondents was 10 speakers chosen from SMIs actors and Regional Apparatus Organization (RAO) related to the development of SMI.

Data analysis uses hierarchical analysis, with the aim of solving complex problems by structuring a hierarchy of criteria in order to develop weights or priorities[9].Hierarchy analysis investigated some of the main aspects in increasing the competitiveness of Halal SMIs including: human resources aspect, financial aspect, production aspect, market and marketing aspect, and Government policy aspect.

\section{RESULTS}

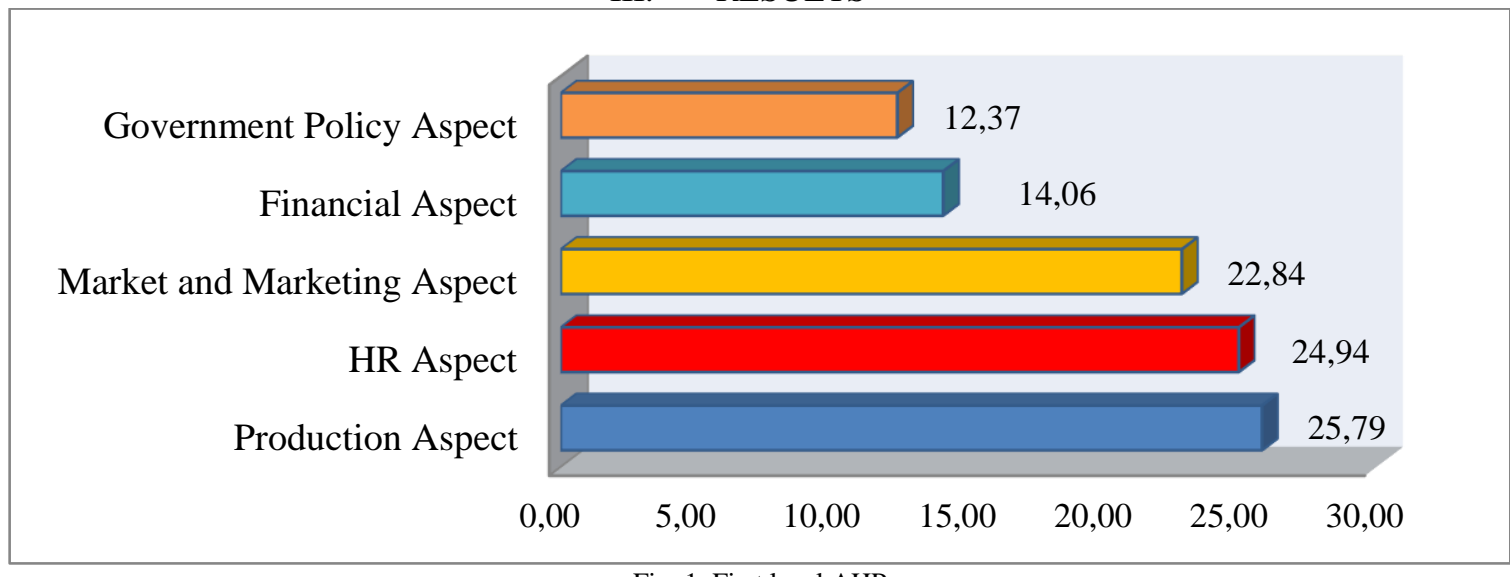

Fig. 1. First level AHP

Based on Figure 1. It was shown that the production aspect was the first priority with a percentage of 25.75 , while the HR aspect was in the second position with a percentage of 24.94 and the market and marketing aspect was in the third position.

TABLE I. SECOND LEVEL AHP OF PRODUCTION ASPECT

\begin{tabular}{|l|l|l|}
\hline Variable & Percentage & Priority \\
\hline Availability of raw materials & 12.90 & 1 \\
\hline Availability of tools and machines & 12.90 & 2 \\
\hline
\end{tabular}

The second level is the variable for each factor in the first level that has been explained previously. In table1. the results of the AHP calculation on the development of Halal SKIs competitiveness were explained from the production aspect which consisted of two variables. Based on the table, it can be seen that the two variables namely the availability of raw materials and the availability of tools and machines were the top priority with the percentage of 12.90 , respectively.

TABLE II. SECOND LEVEL AHP OF HR ASPECT

\begin{tabular}{|l|l|l|}
\hline Variable & Percentage & Priority \\
\hline Level of education & 5.73 & 8 \\
\hline Business experience & 11.23 & 4 \\
\hline Skills & 7.98 & 5 \\
\hline
\end{tabular}

Table I. shows the second level analysis for HR aspect of the development of the competitiveness of Halal SMIs. The top priority wa business experience with a percentage of 11.23. Meanwhile, skills and education level variables occupied the second and third prioritieswith the percentage of 7.98 and 5.73, respectively. 
TABLE III. SECOND LEVEL AHP OF MARKET AND MARKETING ASPECT

\begin{tabular}{|l|l|l|}
\hline Variable & Percentage & Priority \\
\hline $\begin{array}{l}\text { The existence of market } \\
\text { demand }\end{array}$ & 11.58 & 3 \\
\hline Competitive prices & 6.03 & 4 \\
\hline Promotion activities & 5.23 & 9 \\
\hline
\end{tabular}

Table III shows the results of the analysis on the second level for market and marketing aspect in terms of the development of the competitiveness of Halal SMIs. Based on the table, it was known that in the market and marketing aspect, the main priority variable was the existence of market demand with a percentage of 11.58 . Meanwhile, competitive prices and promotional activities variables occupied the second and third priorities with the percentage of 6.03 and 5.23, respectively.

TABLE IV. SECOND LEVEL AHP OF FINANCIAL ASPECT

\begin{tabular}{|l|l|l|}
\hline Variable & Percentage & Priority \\
\hline Owncapital & 7.08 & 6 \\
\hline Availability of banking access & 4.23 & 10 \\
\hline Use of accounting in business & 2.75 & 12 \\
\hline
\end{tabular}

Table IV. shows the results of the analysis on the second level for financial aspect in terms of the development of the competitiveness of Halal SMIs. Based on the table, it was known that in the financial aspect, the main priority variable was own capital variable with a percentage of 7.08. Meanwhile, the availability of banking access and the use of accounting in business occupied the second and third priorities with a percentage of 4.23 and 2.75 , respectively.

\section{TABLE V. SECOND LEVEL AHP OF GOVERNMENT POLICY ASPECT}

\begin{tabular}{|l|l|l|}
\hline Variable & Percentage & Priority \\
\hline Capital access & 1.61 & 17 \\
\hline Coaching activities & 2.85 & 11 \\
\hline Rules and regulations & 2.22 & 13 \\
\hline Provision of information & 1.77 & 16 \\
\hline PIRT certificate ownership & 1.96 & 15 \\
\hline Halal certificate ownership & 1.97 & 14 \\
\hline
\end{tabular}

Table V. explains the results of the analysis at the second level for Government policy aspectin terms of the development of the competitiveness of Halal SMIs. Based on the table, it was known that in the government policy aspect, the main priority variable was coaching activities variable with a percentage of 2.85 . The second priority was the rules and regulations with a percentage of 2.22 . The third priority was halal certificate ownership variable with a percentageof 1.97 . The fourth priority was PIRT certificate ownership with a percentage of 1.96. The fifth priority was provision of information with a percentageof 1.77 and the last priority was capital access with a percentage of 1.61. The order of the priority hierarchy in the development of halal SMIs is shown in table 6 below:

TABLE VI. PRIORITY HIERARCHY OF HALALSMIS VARIABLES IN CIREBON
\begin{tabular}{|l|l|l|}
\hline \multicolumn{3}{|c|}{ Second Level Priority Order (Variable) } \\
\hline Priority & Variable & Weight (\%) \\
\hline P1 & Availability of raw materials & 12.90 \\
\hline P2 & Availability of tools and machines & 12.90 \\
\hline P3 & The existence of marketdemand & 11.58 \\
\hline P4 & Business experience & 11.23 \\
\hline P5 & Skills & 7.98 \\
\hline P6 & Own capital & 7.08 \\
\hline P7 & Competitive prices & 6.03 \\
\hline P8 & Level of education & 5.73 \\
\hline P9 & Promotion activities & 5.23 \\
\hline P10 & Availability of access & 4.23 \\
\hline & Banking & 2.85 \\
\hline P11 & Coaching activities & 2.75 \\
\hline P12 & Use of accountingin business & 2.22 \\
\hline P13 & Rules and Regulations & 1.97 \\
\hline P14 & Halal certificateownership & 1.96 \\
\hline P15 & PIRT certificate ownership & 1.77 \\
\hline P16 & Provision of Information & 1.61 \\
\hline P17 & Capital Access & 100.00 \\
\hline & Total & \\
\hline
\end{tabular}

Table VI. illustrates that theHalal SMIs variable as the main priority for policy making was the availability of raw materials variable (12.90), the second priority was the availability of tools and machines (12.90), and the third priority wasthe market demand variable (11.58).

\section{DISCUSSION}

The results of the study showedthe main priority strateg to improve the competitiveness of halal SMIs. As a whole it was known that the aspects of production, human resources, as well as market and marketing were the core 
of the development priority of Halal SMIs. The result of this study was in line with the finding of Department of Commerce, Cooperatives, Small and Medium Enterprises in Cirebon Districtthat one of the strongest potentials for the development of SMIs was the production aspect. The use of modern tools and machines can create a variety of new products in accordance with market needs and information technology tools, making SMIs able to compete in the global market. Innovation has the potential to increase the value added of the product, so as to minimize the possibility of losses caused by fluctuating prices and competition in similar goods. The importance of product innovation will help businesses to stay and grow towards a competitive position. This type of innovation includes the development of processes, systems and reengineering in activities conducted to develop new products[10].

In this study, halal SMIactrors expected the availability of tools and machines as well as Information and Communication Technology (ICT). The availability of tools and machines is related to the use of Information and Communication Technology (ICT) as an integration platform, which can integrate the competitive advantage of SMIs with a choice of strategies that can add value to long-term business prospects. Potential problems with ICT strategies are information availability and ownership[11].Market demand ranks the 3rd, in line with business development. Currently, many markets are created due to conditions and situations. The strength of SMIs depends on their resilience to the crisis, since most small businesses produce goods and services with a low income elasticity of demand. In such condition, community income does not have much influence on the demand for goods produced[12].

The last priority hierarchical analysis results in this study was capital access. It is in line with several previous studies which stated that the majority of small business actors did not really need access to capital from the Bank. Thus, the implication was that the interest rate and some aspects related to monetary policy did not really affect SMI actors.

In facing competition, business actors as well as the Regional Government must conduct partnerships and good coordination with all parties to in order to create a business and capital system and use of technology that is more effective. The pattern of public-private partnerships has provided many valuable experiences, especially significant in the current situation of the global financial crisis, when many fields of the national economy need state support.[13]

A business system can be formed through a number of strategies, such as expanding product distribution networks, collaborating with SMIs to enter new markets, increasing promotions that are sustainable in order to create market expansion and choosing strategic locations for promotion and sales as access to get consumer[12].

The market and consumers are increasingly wide open and developing, especially Muslims and non-Muslims around the world are increasingly concerned about F\&B products that are in line with the concept of
halalanToyyiban[14].According to (Mohani Abdul), long process and procedure in obtaining halal certification is considered expensive, so small and medium-scale businesses seem not inerested in registering their products [15].

Several respondents revealed that many of Cirebon District's HR potentials had not been developed optimally, such as increasing business experience, and skills of SMI actors. In this case SMIs can take advantage of various training programs organized by Agencies and the Government. It is expected that the competencies of SMIs can be increased and human resource knowledge can be developed. Thus, the risks due to fluctuating raw material prices and commodity quality will be better handled and accompanied by funds for brand enhancement for the business products they manage. The organization can survive, if it can develop its human resources, human resources hold the key to survival, prosperity, economic, and social development in the future.[16]

Regional governments should prioritize increasing capital towards SMIs, especially capital sourced from internal capital before increasing the availability of external access to banks and using accounting in business operations. The increasing amount of capital owned by internal business actors shows the level of independence of a business. The development of Small and Medium Industries (SMIs) is significant for any economic growth. Its essential role in the economic development of any country is even more apparent when the economies of developing countries consider it as the progress of a nation.[17]

\section{CONCLUSION}

The main priority policyin the context of the development of the competitiveness of Halal SMIs at the first level wasthe production aspect. Then it was followed by HR aspect and then market and marketing aspect. As for the second level, the three variables with the highest priority value were the availability of raw materials variable, then it was followed by the tools and machines variable and the market demand variable.

\section{REFERENCES}

[1] A. H. Nu'man, "Kebijakan Pengembangan Industri Kecil dan Menengah sebagai Upaya untuk Menghadapi Era Perdagangan Bebas (Suatu Model Konseptual dalam Pengembangan IKM). MIMBAR," J. Sos. Dan Pembang., vol. 21(3), pp. 388-415, 2005.

[2] Disperdagin, Perkembangan Industri di Kabupaten Cirebon Tahun 2017-2018. Disperdagin Kabupaten Cirebon, 2019.

[3] N. Nurdin, N. Novia, A. Rahman, and R. Suhada, "Potensi Industri Produk Makanan Halal di Kota Palu," J. Ilmu Ekon. dan Bisni Islam, vol. 1, no. 1, pp. 1-12, 2019.

[4] BPS Kabupaten Cirebon., Kabupaten Cirebon dalam Angka. Badan Pusat Statistik Kabupaten Cirebon, 2020.

[5] Y. Heryanto and S. N. Jumiatiningrum, "Koordinasi Bidang Industri Dinas Perindustrian dan Perdagangan Kabupaten Cirebon Dalam Pembinaan Industri Kecil Menengah (IKM) Makanan Olahan di Kabupaten Cirebon," J. Syntax Lit., vol. 2, no. 5, 2017.

[6] Dewi, F. R. Holle, and R. Mustika, "Pengembangan Industri Kecil Tahu Pada Sentral Iundustri Tahu Dan Tempe Desa Sepande Kecamatan Candi Kabupaten Sidoarjo," J. Ilm. UNESA, pp. 1-15, 2014.

[7] E. P. Lestari, "Penguatan Ekonomi Industri Kecil dan 
Menengah melalui Platform Klaster Industri," J. Organ. dan Manaj., vol. 6, no. 2, pp. 146-157, 2010.

[8] K. Yilmaz, "Comparison of Quantitative and Qualitative Research Traditions: epistemological, theoretical, and methodological differences," Eur. J. Educ., vol. Vol. 48, N, pp. 311-324, 2013.

[9] Sumiati, Metode Pembelajaran. Wacana Bandung, 2007.

[10] S. M.S et al., "Innovation Efforts of Halal Food and Beverages Small and Medium Enterprise in Malaysia," Int. J. Acad. Res. Bus. Soc. Sci., vol. Vol. 8, N, pp. 22-30, 2018.

[11] A. M. Bohari, C. W. Hin, and F. Nurwahida, "The competitiveness of halal food industry in Malaysia: A SWOT ICT analysis," Geogr. OnlineTM Malaysia J. Soc. Sp. 9, no. issue 1, pp. 1-9, 2013.

[12] D. Maya, "Pengembangan Unit Usaha Industri Kecil Melalui Metode Pemetaan Dan 'Need Assessment," Pengemb. Unit Usaha Ind. Kecil Melalui Metod. Pemetaan Dan "Need Assessment," vol. 5, no. 1, 2012.
[13] L. G. Rudenko, N. A. Zaitseva, G. E. Mekush, N. V. Dmitrieva, and L. S. Vasilieva, "Improving private sector and government partnership system to support small businesses in the service sector," Math. Educ., vol. 11, no. 5, pp. 1261-1270, 2016.

[14] N. Mahidin, A. M. Saifudin, and S. N. Othman, "Halal Food Logistics: The Challenges among Food \& Beverages Small and Medium Sizes Manufacturers," Int.J sup. Chain. Mgt., vol. Vo. 6 no., pp. 337-346, 2017.

[15] M. Abdul, H. Ismail, M. Mustapha, and H. Kusuma, "Indonesian small medium enterprises (SMEs) and perceptions on Halal food certification," African J. Bus. Manag., vol. Vol. 7(16), pp. 1492-1500, 2013.

[16] P. V. C. Okoye and R. A. Ezejiofor, "The Effect of Human Resources Development on Organizational Productivity," Int. J. Acad. Res. Bus. Soc. Sci., vol. 3, no. 10, pp. 250-268, 2013.

[17] E. C. Gbandi, "Financing Options For Small And Medium Enterprises ( SMEs ) In Nigeria," vol. 10, no. 1, pp. 327-340, 2014. 